\title{
PROCEDURES FOR PUBLIC CONTROL OF REPRESENTATIVE AUTHORITIES IN THE WORLD AND IN UKRAINE
}

\author{
Volodymyr Kuleshov ${ }^{1}$ \\ ${ }^{1}$ Postgraduate student of Regional Policy and Public Administration Chair, Odessa Regional Institute for \\ Public Administration of the National Academy for Public Administration under the President of Ukraine; \\ Chairman of the Hnivan United Territorial Community of the Tyvriv District of the Vinnytsia Oblast, \\ Ukraine, e-mail: volodkulesh2020@gmail.com
}

\begin{abstract}
In today's world, one of the indicators of the level of development of democracy is the level of organization and exercise of public control over public authorities. It should be noted that in Ukraine there is no special law, which establishes the law and determines the mechanism of exercising civil control over the activities of representative authorities, which significantly complicates the procedure for its implementation. Scholars consider the legal basis of public control in the context of legislative and regulatory acts, pointing out their imperfection and expediency of making changes. At the same time, there is no definition of public control in legal documents, and accordingly, the methodology of public control is not defined and therefore there are no methods of its implementation. In scientific and applied publications on the organization of public control of representative authorities in the context of decentralization, it is considered as a component of public participation. The aim of the article: to generalize and systematize foreign scientific and applied research on effective procedures for public control of representative authorities in comparison with the domestic practice. The object of research: implementation of the procedure for public control of representative authorities in foreign countries and in Ukraine. The research methodology: review of foreign and Ukrainian literary sources on the implementation of the procedure for public control of representative authorities in the world and in Ukrainian practice. The obtained results: an analysis of the procedures for public control of representative bodies of power in the countries of the world demonstrates the diversity of approaches to its implementation; forms of public control are enshrined in legal norms and are reflected in the legislation in the form of governmental documents, programs, strategies, standards, or are effectively used without governmental support through e-platforms, panels, etc. As for the Ukrainian scientists, there is no established opinion about the procedures for public control: some identify them with forms of control, others - with the conditions of its effectiveness, some authors place components (stages) of the control process (observation, evaluation, analysis, forecasting) as its methods. The practical significance: adoption of a special law will enable to define general principles of the procedure for public control of representative authorities, and a clear definition will make it possible to determine the nature and set of forms and methods for its implementation.
\end{abstract}

Keywords: public control, public control procedure, representative authoritie, forms of public control, methods of public control.

JEL Classification: J19, L30, L31.

Formulas: 0; fig.: 0; tabl.: 0; bibl.: 13

Introduction. Scholars consider the legal basis of public control in the context of legislative and regulatory acts, pointing out their imperfection and expediency of making changes. At the same time, there is no definition of public control in legal documents, and accordingly, the methodology of public control is not defined and there are no methods and clear procedure for its implementation. In scientific and applied publications on the organization of public control of representative authorities 
in the context of decentralization, it is considered as a component of public participation. This is emphasized by both domestic and foreign scientists.

Ukrainian legal framework for regulating citizens' participation at the local level is quite complex, and local referendums and local participation budget (participatory budget) are not regulated at the legislative level. Ukrainian legislation demonstrates an ambiguous approach to understanding public control. The notion of "public control" is not singled out in the terminology of legislation on the website of the Verkhovna Rada of Ukraine in the section "Legislation of Ukraine: terminology of legislation".

In European countries, there exist a large number of different instruments of local democracy, consisting of various forms of direct and participatory democracy. The procedure for public control of representative authorities includes planning methods which play an important role in its implementation. However, it should be noted that there are no universal forms of participation, although there are some common features and trends adapted by countries at different levels of public management. The activities of citizens and the activities of the authorities in the formation of public control are ambiguous. Most legal acts are aimed at internal organizational control, state control and control of interdepartmental processes.

In Ukraine, public control is seen as a tool for public influence on the activities of representative authorities and carrying out their main tasks. The object, subject and procedure for public control of representative authorities are characterized as the institutional basis of such control. The main procedural forms of public control are: reporting of local government officials, participation of residents of the territorial community in the work of advisory bodies, submission of individual and group appeals, public examination of local government activities and usage of other forms, which are not prohibited by law. Also, the place and role of public expertise are determined, but it is emphasized that its implementation is not a mandatory requirement of the legislation of Ukraine. In the bodies of representative power there are separated internal and external types of control, and their effectiveness depends on the procedure of their implementation.

Literature review. The analysis of scientific achievements allowed to single out procedural aspects of public control of representative authorities and to single out the best practices for its implementation. Both domestic and foreign researchers have dealt with this issue. Foreign practice demonstrates the opposite approach to the definition of public control, the procedure for its implementation is based on a certain methodology, which contains a sequence of methods and techniques, a clear description of the means of control procedures and preparation of a final report containing the relevant results and outlines further cooperation. The main procedural form is dialogue, which is characterized as the basis for cooperation, built on twoway communication and aimed at establishing understanding between all its participants. 
German scientists Dr. Jan-Hendrik Kamlage and Prof. Dr. Patrizia Nanz (2009) in their research focus on the forms of structured participation and democratic decision-making. Scholars emphasize that public participation can contribute to the development of the three basic democratic values: legality, justice, the effectiveness of governmental decisions and public control over their implementation.

One of the best foreign representative practices, according to O. Maksimova (2010), is the experience of Canada. Under Canada's federal system, government power bodies are divided between the federal government and 10 provincial governments. Citizens of Canada elect representatives who will represent their interests at various levels: federal, provincial, or territorial and municipal (local). The Constitution of Canada guarantees various areas of responsibility for the federal parliament and provincial legislatures. According to the Constitution, the Parliament has power in the territories, but in practice much of this power is given to the independent disposal of the territories. The activities of local municipalities are not defined in the Constitution, but each province creates its own local elected bodies and assigns them a certain range of responsibilities. The Parliament of Canada develops legislation for the country as a whole, while the legislatures of the provinces or territories create laws that apply only within the respective provinces and territories.

The activities of local municipalities are not defined in the Constitution, but each province creates its own local elected bodies and assigns them a certain range of responsibilities. The Parliament of Canada develops legislation for the country as a whole, while the legislatures of the provinces or territories create laws that apply only within the respective provinces and territories.

Norway is a parliamentary constitutional monarchy in the form of public administration, a unitary state based on the principles of a constitutional monarchy and parliamentary democracy. For more than 170 years, citizens have been electing their own representative bodies in municipalities and local councils.

It should be noted the positive trend of increasing the democratic role of local and county authorities, the state supports the concept of "welfare state" around local and county authorities, which are responsible for the quality of public services. Local and county authorities are interested in involving citizens in local government and the constant exercise of public control by residents, as it is the responsibility that underpins the democratic system. The local administration takes into account public opinion, constantly determines the level and quality of municipal services and monitors the local budget. The very concept of the municipality is connected with the idea of community - the local community and its inhabitants perform common tasks, make joint decisions and identify problems for further solution. This includes the involvement of citizens in the decision-making process of the municipality and local council on the basis of responsibility not only of officials but also of residents. One of the most important activities of the local council is to determine the best alternative and make an appropriate decision based on it. 
In Sweden, the system of administration is based on the power of the people. Citizens have the right to vote, thus determining which political party will be represented in the Swedish parliament, district councils and municipalities. Other ways to influence Swedish politics are to participate in referendums, join a political party or participate in the discussion of reports submitted by the government.

In his research, David Coleman (2016) emphasizes that Australians are proud to live in a consolidated democracy and characterize their society as a society of free citizens. However, according to Australian experts, citizens need to intensify their participation in political life and be able to prove their own public position. In this regard, Australia is systematically conducting national debates, based on a reflexive approach, according to which a problem is identified and who has the right to solve it. According to the organizers of a national debate, the lack of public control leads to the formation of the idea of a public authority body at any level that just this body is the source of power. Emphasis is placed on certain responsibilities of the individual and the responsibilities of the government.

The report of the Directorate General of Democracy (2017) together with the European Committee for Democracy and Governance (CDDG) presents the existing international norms and standards of citizens' participation enshrined in the documents of the UN, Council of Europe, OSCE and the European Union. They are constantly updated due to the appearance of new technologies and new forms of participation.

Experts of the Council of Europe (2017) analyzing the best practices for the implementation of standards of citizen participation in Poland characterize the dialogue as the main form of cooperation, which is based on two-way communication and aims to establish understanding between all its participants. The main tools are: ongoing public hearings and public forums with stakeholders (rather than temporary on specific issues; interagency councils with NGOs on specific issues; key contact in the government agency to liaise with NGOs; capacity building measures to increase knowledge and potential for public participation).

In some domestic studies, there are procedures for exercising public control. V. Boklag, A. Pavlenko (2017) emphasize that the procedure for exercising public control should be prescribed in the statutes of territorial communities.

L. Nalyvayko, A. Oreshkova (2016) distinguish the procedure for organizing and conducting public expertise, referring to the research of other authors, namely: determining the sphere or direction of the authority for conducting public expertise; planning of public expertise; determination of the purpose and tasks of public expertise; formation of a group of public experts; development of methods for conducting public expertise; preparation of a request for public expertise; conducting public expertise; registration of the results of public expertise; public discussion of the results of public expertise; organization of control over taking into account recommendations based on the results of public expertise. 
The Council of Europe's report on the implementation of the best democratic practices describes the public participation matrix, which is set out in the Code of Good Practice for the Preparation and Application of Standards in Decision-Making and distinguishes four levels of participation. It should be noted that each level is characterized by appropriate methods.

The Code of Good Practice for Public Participation in Decision-Making (2009) sets out general principles, procedures, tools and mechanisms for the active participation of NGOs, which are used by almost all European countries with democratic regimes.

Aims. The aim of the article is to generalize and systematize foreign scientific and applied research on effective procedures for public control of representative authorities in comparison with the domestic practice. The object of research: implementation of the procedure for public control of representative authorities in foreign countries and in Ukraine.

Methods. The research methodology: review of foreign and Ukrainian literary sources on the implementation of the procedure for public control of representative authorities in the world and in Ukrainian practice.

Results. The analysis of scientific publications demonstrated diametrically opposed views on the understanding of forms, methods, procedures, mechanisms, technologies, tools for public control. Forms of public control include: monitoring and coverage of its results; strategic planning; program development; public hearings; examination; creation of public advisory and supervisory committees, councils, control committees, inspections, etc.; general meetings; independent budget analysis; reports; congresses and conferences; forums and gatherings; rallies, demonstrations, pickets; sociological and statistical research; public expertise; publications in mass media; participation in the activities of collegial authorities; inspections; analysis of citizens' appeals; local initiative; electronic petitions, consultations; supervision; people's legislative initiative; cooperation.

Functions of public control are reduced to drawing the attention of the authorities to the problems, eliminating abuses by public administration entities; human rights monitoring; improving the quality of public services, the work of public administration; journalistic investigations; access to information; "Jury trial"; public investigations, etc. In some studies, these functions are understood as mechanisms, methods, technologies or tools of public control. Means of public control are considered through the possibility of expression of the will of citizens (direct/ indirect). Public control and involvement of citizens are understood as synonyms, that is why methods of involving citizens are considered as methods of public control, which leads to the formal perception of the notion of "public control" itself both as a phenomenon and as a process.

Based on the analysis of foreign and domestic sources, procedures and methods of public control are classified according to the levels of public participation (in 
accordance with the matrix of participation according to the Code of Good Practice for preparing and applying standards in decision-making; Council of Europe).

The following methods are typical for the highest level (partnership): methods of regulation, method of public order, procedural method, information method, educational method, contractual methods, conciliation methods, methods of reconciliation, participatory methods, methods of involvement, methods of joint activity, method of joint decision-making, design method, method of social design, methods of strategic partnership (introduction of appropriate techniques to implement the functioning of an effective system, understanding of each participant, joint activities in accordance with the interests of each participant, coordination of actions based on the principles of equality, voluntariness, openness, transparency).

At the level of establishing the dialogue, the following group of methods is distinguished: methods of establishing contact, methods of communication, methods of discussions, planning method, method of coordination, communication methods, methods of manipulation, methods of propaganda (application of the corresponding methods is relevant in building up a dialogue between public authorities and public societies, whose actions are aimed at establishing a consolidated democracy based on the principles of an open society. Dialogue is an effective approach to building trust between citizens and public authorities, based on understanding and mutual responsibility).

Discussion. Consultations are carried out on the basis of the following methods: methods of management of social and mass processes, methods of management of groups, methods of management of groups and processes, methods of social regulation, methods of manipulation, methods of suggestion, methods of role changes, methods of prevention, ideological methods, method of influence, methods of planning (introduction of a system of such techniques is directed to interest and involve the citizen into a discussion on politics (at any level), from this position consultations contribute to bringing up the citizen to a higher level of the "dialogue").

As for the level of influence, the main methods are: methods of informing, methods of coercion, methods of suggestion, method of explanation, method of obtaining data, method of initiatives (the systems of techniques is aimed at identifying possible trends of policy consequences, studying public opinion, attitudes and expectations of the public directed to monitoring the corresponding changes).

In Ukraine, to some extent, there has been formed such legislation, which defines forms and methods of public control in the context of decentralization. However, it should be noted that the activities of civil society organizations in exercising public control and conducting public expertise need to be improved, in particular: comprehensive work of representative authorities at all levels is required, ensuring effective public advisory bodies and transparency, openness and public participation.

Conclusion. The analysis of foreign and domestic sources has shown that the legal basis of public control of representative authorities in Ukraine differs from 
foreign countries in the following: lack of a clear definition of the notion "public control"; absence of this notion in the terminology of legislation; lack of standards of public control; limited methods and techniques; the presence of administrative procedures that nullify it; scattered statements about the rights of citizens to hold it; lack of public policy in this context and the effectiveness of public control ("advisory voice"). Foreign experts emphasize the imperfections of Ukrainian legislation in the context of public participation and public control as its component. This view refers to the "local participation budget", too.

In terms of methodological approaches to the organization of public control, the dominant issues are the establishment of cooperation between public administration subjects and administration through the processes of openness, transparency, accessibility of information. Influence on public authorities by the public comes from the standpoint of the creation of advisory bodies, rather than the formation of public control (both organized and individual). However, even in the existing practices the optimal format of their work is not developed.

These findings prove the feasibility of developing a methodology for public control of representative authorities in small and medium-sized towns of Ukraine, as they can involve the largest percentage of the community in the management of public affairs.

\section{References:}

1. The System of Public Administration of Canada: Experience for Ukraine / comp. O.I. Maximov; general ed. Yu. V. Kovbasyuk. Kyiv: NAPA, 2010. 60 p.

2. Civic participation in decision-making: An overview of standards and practices in Council of Europe member states. Strasbourg, May, 2016. Retrieved from: https://rm.coe.int/civil-participation-in-decisionmaking-processes-an-overview-of-standa/1680701801.

3. Boklag, V., \& Pavlenko A. (2017). Public control in the context of unification of territorial communities and decentralization in Ukraine. Actual problems of public administration. №1 (51). Retrieved from: http://www.irbis-nbuv.gov.ua/cgi-

bin/irbis_nbuv/cgiirbis_64.exe?I21DBN=LINK\&P21DBN=UJRN\&Z21ID=\&S21REF=10\&S21CNR=20\&S

21STN=1\&S21FMT=ASP_meta\&C21COM=S\&2_S21P03=FILA=\&2_S21STR=apdy_2017_1_11.

4. Nalyvayko L., \& Oreshkova A. (2016). Public expertise of the activities of public power bodies in the context of modernization of the Ukrainian society. Young scientist. № 2 (29). Retrieved from: http://molodyvcheny.in.ua/files/journal/2016/2/48.pdf.

5. Jan-Hendrik Kamlage, \& Patrizia Nanz. (2019). Public Participation and Democratic Innovations: Assessing Democratic Institutions and Processes for Deepening and Increased Public Participation in Political Decision-Making. Retrieved from: https://rm.coe.int/public-participation-and-democraticinnovations-assessing-democratic-i/168075f47b.

6. More about local democracy. (2011). Retrieved from: https://www.regjeringen.no/en/topics/electionsand-democracy/lokaldemokrati/the-mayor/id550479.

7. Sveinung Arnesen, \& Yvette Peters. (2017). The Legitimacy of Representation: How Descriptive, Formal, and Responsiveness Representation Affect the Acceptability of Political Decisions. Comparative Political Studies. № 51. P. 868-899. Retrieved from: https://journals.sagepub.com/doi/full/10.1177/0010414017720702.

8. The Swedish system of government. (2003). Retrieved from: https://sweden.se/society/the-swedishsystem-of-government.

9. Coleman D. (2016). Australian public needs to wrest more control back off the government. Retrieved from: https://www.afr.com/policy/australian-public-needs-to-wrest-more-control-back-off-the-government20160821-gqxixc 
10.Participatory democracy tools: European standards and practices. (2017). Retrieved from: http://www.slg-coe.org.ua/wp-content/uploads/2017/04/CoE_Opinion_Participatorydemocracy_SAGUDLPO20171_.pdf

Received: August 04, 2020

Approved: September 12, 2020 